KATARZYNA DĘBSKA (D)

University of Warsaw

\title{
IT'S LIKE GOSSIP: PROBLEMS AND ETHICAL CHALLENGES IN SOCIOLOGICAL QUALITATIVE RESEARCH ON RELATIONS BETWEEN ADULT SIBLINGS ${ }^{12}$
}

\begin{abstract}
In research on family relations (between mothers and daughters, intimate partners etc.) various research methods are used (individual interviews with family members, dyads, focused group interviews, ethnographic observation) in order to learn the variety of perspectives and experiences of family members. Such an approach enables a researcher to analyze the problem in a more multidimensional way in comparison with a situation when the research is conducted only with one of the family members. However, engaging more research participants, who are often tied to each other with complicated emotional bonds, creates various ethical and methodological challenges. Considering this issue, I refer to my experience in conducting research on the dynamics and forms of adult siblings' relations through their life course.
\end{abstract}

Mgr, doctoral candidate, Faculty of Sociology; e-mail: k.debska@is.uw.edu.pl; https://orcid.org/0000-0003-4802-7686

1 This article was written as a part of research internship at the Faculty of Sociology, Social Policy and Criminology at the University of Southampton (United Kingdom) which was supervised by prof. Rosalind Edwards and financed by the financial support programme for research and teaching purposes for doctoral candidates at the University of Warsaw in 2019. This article is based on one of the chapters of author's PhD thesis.

2 The author is grateful to the editors of this issue and anonymous reviewers for their helpful comments on the article which positively have influenced its final version. 
I conducted interviews with 41 women and 14 men (in 7 cases more than one sibling from a family took part in my research). In the rest of the cases my interviewees rejected the possibility of my contacting their siblings. In this article I discuss issues concerning the recruitment of research participants belonging to the same family, managing data confidentiality when individuals who know each other are interviewed, and the dynamics of power relations between the researcher and the research participants.

Keywords: data confidentiality, siblings, qualitative interviews, relations between a researcher and research participants

\section{INTRODUCTION}

Ever since the emergence of sociology as an academic discipline, family has been an important object of its interest. Distinctively though, sociologists have focused primarily on vertical (inter-generational) relationships in a family or relationships between intimate partners. Horizontal kinship relationships were analysed much earlier by anthropologists [see, for example, Lévi-Strauss 2009, Malinowski 1984] or psychologists rather than by sociologists. These two disciplines, psychology in particular, due to its pervasiveness in modern societies, constitute a constant reference point in research on siblings. Psychoanalysis, dealing with kinship relations and mechanisms of shaping personality and interpersonal relationships, could not completely overlook sibling relations either [see, for example, Coles 2015; Mitchell 2014].

The research on relationships between siblings and biographies of people raised by the same parents (or at least one common parent) in the same family of origin open numerous opportunities for sociological analyses ${ }^{3}$. It enables researchers to raise questions not only about family life practices and identity development, but also about the way in which individuals negotiate distance and closeness, equality and differences or justice and solidarity in close relationships. At the same time, however, similar to other research on close relationships, studies with siblings as participants require sociologists to ensure particularly high ethical standards as people participating in such studies reveal to researchers details about their own personal life, as well as that of their relatives. Qualitative

3 In addition, psychology often made use of a common gene pool shared by siblings; researchers assumed that it may provide an answer to the question of what - biology or upbringing - determines personality features and behaviour of individuals. 
interview, which to a certain extent resembles an everyday conversation, begins "gossiping", as one of the participants of my study put it at the end of our talk

The participants in my research included individuals, as well as two, three and four siblings. The goal of this article is to discuss the ethical and methodological challenges I encountered during my research on how the relations between siblings change over a lifetime. In particular I would like to focus on problems which arise in studies where participants know and are close to each other. A vital context of my research, which needs to be highlighted due to the difficulties it creates, is the aforementioned lack of recognition of the topic in question in the Polish academic milieu. Such a situation affects the process of collecting research material in two ways: on one hand, recognising the importance of the issue under consideration makes it possible for the researcher to win over those who also share the same view; on the other hand, it requires her to provide the potential participants, as well as the audience, with convincing arguments in terms of why her research has a potential to enrich our knowledge of family relationships and, more broadly, show the significance of horizontal relationships in the processes of socialization.

This article begins with a short overview of the status of research on siblings in sociology, psychology, and psychoanalysis. Although my article focuses on problems and challenges of a methodological and ethical nature, presenting briefly the current status of the research and recognition of this problem in the Polish sociological field will provide a context for my study.

Then I move on to characterise the research conducted for the purpose of my $\mathrm{PhD}$ thesis, the goal of which was to analyse the course of relationships between siblings over their lifetime, as well as the contexts which shape different types of such relations. I emphasise those methodological and ethical issues which in the course of the study proved problematic. In the next section, I analyse issues related to recruiting research participants, managing the confidentiality of information in cases of interviews with research participants who know each other, and power dynamics in the field. Here, I refer to the experiences of other researchers, and attempt to provide possible solutions to the challenges which I faced during the research process.

\section{SIBLING RELATIONSHIPS AND THE IDENTITY OF BROTHERS AND SISTERS FROM THE PERSPECTIVE OF SOCIAL SCIENCES}

Researchers interested in studying siblings (especially adult brothers and sisters) for long time faced the challenge of a relatively small amount of work addressing this topic, which was largely neglected by the social sciences. In psychology, 
at the beginning of the $20^{\text {th }}$ century, Alfred Adler put forward a proposition on the crucial importance the order of birth has for the further development of a child, its personality traits, and success in adulthood. For a long time, psychological research was focused on quantitative analyses of sibling relationships and the characteristics of brothers and sisters according to the order of their birth, age difference in relation to other siblings, etc. This approach was met with criticism due to its monocausality [Kasten 1997]. The course of siblings' biographies and the shape of the relationships between them are affected by various factors (e.g., gender, situation of the family of origin, and dominant patterns during upbringing), including positive and negative events which from the perspective of an individual happened by chance (e.g., the sudden upturn in the family's economic situation, the outbreak of war, the death of a parent) [see also Conley 2004; Kasten 1997: 41-45]. However, according to the aforementioned authors, a person's luck is actually rarely accidental, independent of various structural factors (such as, for example, socio-cultural gender). The breakthrough in psychology and psychoanalysis came with the works of Stephen P. Bank and Michael D. Kahn [1982], as well as Juliet Mitchell [2003]. Since then numerous other works have been published which focus on sibling relationships from a therapeutic point of view [e.g., Milevsky 2016; Rustin 2018].

In Polish literature devoted to siblings publications are predominantly from the field of psychology. Authors in this field focus (among others) on the functioning of only children, the influence of having siblings on the ability of a child to find their way as a student [Tyszkowa 1985; Litwińska 2010], and the relationship of siblings when one of them is ill [Pisula 2007; Pawlak 2013]. Psychologists are also interested in twins and the relationships they establish with others [Rostowska 2010].

In Polish sociological literature sibling relationships have usually been discussed on the margins of other topics: for example, in the context of analysing the biographies of people who experienced upward mobility [Ferenc 2012], considerations of the possibility and biographical consequences of an individual leaving the family [Urbańska 2014], relations in extended families in the upper class [Smoczyński, Zarycki 2017], or in reference to relations of non-heterosexual persons with members of their families of origin [Mizielińska 2017]. The handbook on family sociology by Tomasz Szlendak does not discuss siblings as a separate topic [Szlendak 2015]. In her work Family made in Poland devoted to kinship relations in Polish families, Agata Stanisz analyses kinship in wider networks than just those delineated by the nuclear family model [Stanisz 2013]. In the Polish sociological field, so far research on the importance of having siblings 
in the life of individuals has been largely limited to survey research [Przybył 2017], providing us with knowledge about the attitude respondents have towards their siblings and to the idea of having siblings in general.

The need for a truly interdisciplinary approach to this issue is evidenced by the fact that many researchers in the social sciences, just like the author of this article herself, refer in their works not only to various social theories, but also to approaches developed within the fields of anthropology, psychology, and psychoanalysis. Rosalind Edwards, Lucy Hadfield, Helen Lucey, and Melanie Mauthner in their work on relationships between brothers and sisters in childhood and adolescence build on, among others, a psychodynamic perspective [Edwards, Hadfield, Lucey, Mauthner 2006: 12]. Referring to the findings of psychology and psychoanalysis is so important because, as authors such as Prophecy Coles [2003] and Juliet Mitchell [2003] claim, it was the work of Sigmund Freud, the father of psychoanalysis, that defined the horizon of interests for many psychoanalysts, psychologists, and sociologists to come. In his works, Freud put a special emphasis on vertical relationships in a family (between a parent and a child) and conflicts of the Oedipal nature, which must be addressed and solved at the appropriate stage of childhood so that the psychological sphere of an individual can function properly. At the same time, however, as Susan Sherwin-White points out, Freud repeatedly discussed in his works the importance of having siblings for an individual's mental development [Sherwin-White 2007].

Social research can greatly contribute to our understanding of horizontal relationships within the family and in wider social networks. Sociological concepts, such as ambivalence in family relationships, care giving, or gender patterns are all topics which attract great interest among researchers who study siblings in the context of the human course of life. On the basis of sociological research on sibling relationships, it is possible to reconstruct the trajectories of closeness and distance between brothers and sisters over the course of their lives [see, for example, Connidis 2007; Edwards, Hadfield, Lucey, Mauthner 2006; Gold 1989].

\section{THE CHARACTERISTICS OF MY RESEARCH}

The theoretical perspective I adopt in my study is based on an intersectional approach to family relationships rooted in social class structures [Bourdieu 2005; Ferenc 2012; Skeggs 1997; Smoczyński, Zarycki 2017] and the diversity of social forms of masculinity and femininity. Socio-cultural gender affects all dimensions of social life: on an individual level (individuals' attitude towards themselves, their identity, and socialisation), on an interactional level (relationships with 
other people, cultural expectations, a priori assumptions we all make), and on an institutional level (distribution of material resources, functioning models of formal organisations, and ideological discourses) [Risman, Davis 2012: 9].

While analysing the biographies of my interviewees and the stories they told me about their siblings, as well as the dynamics of relationships between brothers and sisters in the course of their lives, I focused on one question in particular - hether it is possible to distinguish the various types of relationships and the contexts of their formation. My study, apart from the issues listed above, in particular showed crucial importance of class reproduction and breaking the limits it imposes (this is actually one of the major research questions of my project), as well as issues related to reciprocity, recognition and family violence (among siblings and parents-towards-children).

\section{SELECTING RESEARCH PARTICIPANTS}

Data was collected from 41 women and 14 men aged 21 to 86 . In seven cases I was able to invite more than one sibling. In six cases I had two participants from the same family (in one case the older brother of my interviewees was deceased, in the second one a younger sister did not participate in the study, in the third one I interviewed two out of five siblings, in two cases my subjects did not have any more siblings), in one case I interviewed three sisters out of four, and in another I was able to contact four siblings out of five. The complexity and diversity of the cases selected for the study are connected to a non-exclusive and reflexive nature of the relationship between siblings and the identity of brothers and sisters. Other researchers studying relations between brothers and sisters and their biographies also construct case groups in a complex and diverse manner [cf. Mauthner 2002; Edwards et al. 2006; Conley 2004]. In those studies, and also in my own research, participants were pairs of siblings and larger sibling groups.

In sociology, the strategy of engaging people who are close to each other in a study is often used to study couples and intimate relationships. One of the first studies of this type was conducted by Jessie Bernard [1972] on marital relationships. In the area of sibling research, a multitude of perspectives of brothers and sisters were included, among others, in the works of Edwards, Hadfield, Lucey and Mauthner [2006] in their analysis of sibling relationships in childhood, Melanie Mauthner [2002] in her study on relationships between sisters, and Miri Song [1998] who analysed the involvement of brothers and sisters in helping with family businesses. Sociological literature presents various approaches to conducting research with more than one family member: Some researchers 
interview all participants separately [e.g., Hertz 1995; Korolczuk 2019], others talk to all participants at the same time [e.g., Graham 1980; Sikorska 2019] or combine these two approaches [e.g., Olcoń-Kubicka 2017; Mizielińska 2017]. Melanie Mauthner [2002: 177-182] in her study on sister relationships, conducted interviews in various configurations: sometimes separately with more than one sister, sometimes with sisters in pairs or in a group of three.

Each of these approaches has its own advantages and disadvantages. On one hand, in the case of pairs, triads and group interviews, certain contentious issues in relations between the interviewees (as highlighted in studies of intimate couples) may never be voiced. On the other, such a formula can impede obtaining nuanced stories about subjects' experiences when a conversation with the researcher takes the form of a preparing non-compliance report on presenting the discrepancies in the memories of brothers and sisters. Cognizant of the fact that relationships between adult siblings can take highly diverse forms and can be characterised by intensified antagonisms, I decided to conduct separate interviews when two or more members of the same family decided to participate. I wanted to hear individual stories and focus on their unique points of view instead of having to verify them by collating data provided by different people who share the experience of being in family relationships. For some people, talking with another person (here: the researcher) about their relatives may be questionable, depending on what issues they consider too intimate or private. One of my interviewees, in answer to my question about his relationship with his sister, summed our conversation up as: "It's like gossip", a phrase which I decided to incorporate in the title of this article. Melanie Mauthner [2000: 304] describes the sisters of her interviewee who decided against participating in her study as "involuntary participants" and writes their names in italics (I adopted the same strategy in my research). It should be noted that some of the brothers and sisters of my interviewees knew that their siblings participated in my study, while others did not, which made them involuntary participants of my research.

As the phenomenon I chose to study is not well-recognized in the Polish context, my research was largely exploratory in nature. I began the study with no certainty about whether potential participants would find its goal attractive enough to decide to participate. I did not seek the assistance of recruitment agencies who recruit research subjects for remuneration. Recruitment was conducted by myself and with the help of people who knew what kind of participants I was looking for. Those who decided to participate in the study also helped me to reach others. 
At first, I assumed that I would to talk to all adults biologically related to each other as brothers or sisters (eligibility criteria required participants to have common parents; naturally, at the same time I was fully aware of the cultural and social dimensions of kinship). However, finally I decided to abandon this approach, having analysed the works of other social researchers who did not always include all the siblings when examining the ties between brothers and sisters [cf. for example Mauthner 2002; Edwards et al. 2006]. Excluding cases of "single" interviewees would lead to (in accordance with my expectations at the beginning of the study) a further exclusion from the research of those families where brothers and sisters were not on good terms either due to a conflict, or did not maintain any contact at all. Korolczuk [2019] in her research on mother-daughter pairs points out that her interviewees were at least on relatively good terms; otherwise it would have been difficult to expect the first participant, usually a daughter, to want the researcher to have contact with her mother.

My research, however, was also aimed at reconstructing those difficult, antagonistic relationships between siblings. I could not expect individuals who did not maintain any contact or avoided each other to take steps to break the existing distance for me. Even a mere disclosure of their participation in my research could have negative consequences for them. Adopting this strategy could also prove detrimental to my study in terms of the quality of information: Those who decided to participate in my research could either withdraw from the study altogether, or auto-censor their statements if they did not want to reveal the tensions between themselves and their siblings.

Collecting contacts to my interviewees' family members was on a snowball method. Those who decided to participate in my research asked their siblings whether they would like to contact me. In most cases, my interviewees either decided to inform their brothers and sisters about my research, or gave various reasons for why they could not. In those instances where my interviewees were enthusiastic about the research and were willing to persuade their siblings to participate, I was usually able to conduct further interviews. Less engaged participants often promised to ask their siblings whether they would like to talk to me too; however, in such cases their brothers and sisters usually did not contact me at all. I usually did not receive any confirmation from them. The key factor seemed to be the willingness of my interviewees to convince their brothers and/ or sisters to meet with me. Some participants were even convinced their siblings would agree, and in such cases agreement was usually forthcoming. Sometimes they gave me the contact information of their brothers/sisters, in other cases it 
was their siblings who contacted me. I found it significant that I did not have an opportunity to talk with two (or more) siblings of different generations or, as Edwards et al. [2006: 42] put it, in the case of which there was a significant age gap. Children born at long intervals often function in a family like only children. In this group of cases this model was particularly noticeable in families where the youngest child was born when older siblings were already in their teens. In many cases a significant age gap results in significant differences in experiences, including experiences related to being raised by parents at different life stages, which in turn affects their views, parenting approaches, etc. Those of my interviewees who were in such a position often did not have a close bond with their younger siblings; a sense of a certain community they shared with brothers and sisters of a similar age.

The reasons my interviewees provided to justify their decision not to contact me with their siblings were threefold. First, in some cases contact was impossible for technical reasons (e.g., their brother/sister was abroad). Second, sometimes my interviewees did not want to provide me with contact information because their brother or sister happened to be in a difficult situation at that time (e.g., one of the participants argued that her brother was suffering from divorce-related stress, and that was why she did not want to involve him in my research). The third reason was related to either a strong conflict between the siblings or not maintaining any contact whatsoever. In such instances I could not expect my interviewees to break down these barriers for the purposes of my study. At first, I assumed that the optimal solution would be to gather material including the perspectives of all siblings in a given family. However, during the empirical part of the study it became clear that adopting this method would entail losing access to a wide range of experiences. In this way, the opportunity to reach to the difficult aspects of having siblings, often entailing suffering, would be lost.

I decided to consider sibling configurations with various age and gender differences, instead of focusing on the widespread premise in literature (albeit often challenged) [see, for example, Conley 2004] of the dimensions which are key to relationship development: the birth order, the number of siblings, and the age difference between siblings. Obviously, a decision to design a sample in such a way precludes what would be described in a quantitative study as a control over the structure of a sample. At the same time, however, it allows for a comparison of cases which are either very similar or significantly different (in accordance with the principle of minimum and maximum difference). 


\section{CONFIDENTIALITY OF INFORMATION AND ANONYMITY OF RESEARCH PARTICIPANTS}

Ensuring the anonymity of research participants and confidentiality of sensitive information are the primary recommendations researchers find in academic textbooks [see, for example, Hammerslay, Atkinson 2000]. When compiling and preparing the data to present to various audiences, on one hand I had to make sure that participants would not suffer any negative consequences following my research (e.g., in the form of sensitive information about them being disclosed either to a wider audience, or to those who knowing certain facts of their lives might be able to identify them). On the other hand, I had an obligation to remain faithful to the material I had collected. A tension between these two commitments is a common problem in qualitative research.

The analysis of individual cases, which typically requires presenting a considerable amount of biographical detail, poses numerous challenges to anonymity and confidentiality. The need to go into detail while forming their biographical narrative sometimes prompts an individual to reveal deeply intimate information, the lack of which might lead to incomprehensibility of the entire narrative to its readers [Kaźmierska 1997: 40]. Similarly, a thorough analysis of a single story about someone's own biography and the history of their relations with their brothers or sisters becomes difficult if we decide to omit certain information. At the same time, however, going into detail increases the risk of revealing the participants' identity; in final publications they can not only identify themselves but others might also be able to identify them. In anonymising transcriptions of my interviews, I adopted the strategy of "blurring traces": I changed certain data which were to appear in my publication (which were less significant from the point of view of an analysis), and some data were replaced by other data in a way which would not affect the results (for example, an information that a participant is a University graduate). However, certain data relevant to the analysis could not be presented in publications because the likelihood of revealing the identity of my interviewees was too high. Conversations I had with them about their biographies and the biographies of their siblings gave me access to an incredible wide range of information about the entire family.

Interviewing people who remain close to each other requires a reconsideration of how the previously gathered information can be used in the rest of the data collection process. I decided not to use or disclose any information obtained in a conversation with one person in an interview with their family member. The exception was made only in terms of obvious facts that were well-known in a given family. For example, I exchanged some comments with a brother of my 
first interviewee about her little daughter who was present when I interviewed her mother. Researchers who use a similar method of data collection approach this problem in various ways. Elżbieta Korolczuk [2019] describes her strategy primarily in terms of a flexibility and willingness to adapt to the needs expressed by her participants. Some participants explicitly asked her not to disclose certain information to their daughters/mothers. In many situations, however, they did not address this issue at all, in which case the researcher understood that the decision was hers to make. Korolczuk points out that "if two family members participate in a study, they realise that the information they provide may be compared with what the other respondent had said; they may also be concerned about the potentially sensitive issues being passed on to others" [Korolczuk 2019: 251]. Although the research participants were aware of the fact I would be talking to their relatives also about them, I did not disclose anything that I had learned in the previous stages of the research process during my interviews; this could also be problematic: If I suggested that I lacked knowledge about some topics related to the life of a given family might give the impression that I had not listened carefully enough to my previous interviewees. As I emphasise in the section on the methodology of conducting interviews, the fact that my interviewees realised that I might already possess certain information about the life of their family might affect the scope of my access to data in various ways.

Throughout the research, I never felt that any of the participants were trying to trick me into revealing information I had gained while talking to their sibling(s). In the second and subsequent interviews with members of the same family, I experienced all kinds of difficulties arising from the specifics of the adopted research methodology. Sometimes my interviewees informed me of a problematic issue in the life of their brother/sister who in a conversation with me was silent about that fact (for example, a sister's conflict with parents over her religious choices or the problems at school of one of the brothers). In my conversation with such a participant, I did not touch on the topic so as to avoid revealing that I knew about it. When I interviewed the first of several siblings, I often heard that their brother/sister would likely tell me about this or that situation.

\section{THE PRACTICE OF CONDUCTING INTERVIEWS WITH BROTHERS AND SISTERS}

Designing the tools for my study, I drew inspiration from the methodology of autobiographical narrative interview [Rokuszewska-Pawełek 1992; Kazmierska 1997; Bertaux 1996). At the beginning of each interview, I asked my interviewees 
to tell me about their life and the life of their siblings in a free-flowing manner in the way they wanted to, without any suggestions from me. Such an introduction was intended to stimulate participants to create narratives; however, in many cases they expected the researcher to help them by asking them questions. The interviews I obtained were partly narrative, by which I mean that for a relatively long period of time my participants elaborated on particular issues on their own and moved on from one thread to another without any prompts on my part. Because of the multitude of threads, I had to frequently inquire about various factual details and interpretations; for this reason, these conversations were usually in the form of semi-structured in-depth interviews.

Family researchers emphasise the importance of considering the experiences and perspectives of different people involved in a given relationship [see., for example, Hertz 1995; Willson, Shuey, Elder, Wickrama 2006: 235]. Interviews in dyads, triads, or groups would present an opportunity to obtain highly interesting research material, but they would not provide the opportunity to answer the research questions which I posed. The presence of other people affects how an individual formulates their story [see, for example, Taylor and de Vocht 2011]; it may also prompt respondents to censor their own statements. A few of my interviewees who involved their siblings in my research, actually did consider a joint interview with their sister; however, in the end I decided against it, as in such interviews certain topics may be omitted, or not even considered relevant. Thus, in most cases I interviewed only one family member at a time. In the course of our conversations I learned the story of their lives, their siblings, and the history of their mutual relationship. In some studies, which adopt an entire family as an analysis unit, it is usually one of its members who is actually involved in the study, answering the researcher's questions on behalf of the entire family [Palska 2002: 34]. However, in my research the unit of analysis was the individual, their experiences and the way they perceive them. I also asked one family member about the others, but in the context of their experiences, not their particular position in the family (e.g., being the oldest of all siblings).

In the course of conducting my research, on some occasions the interviewees whose siblings I was to interview at a later time, claimed they lacked full knowledge on the subject I was interested in, or even refused to comment on a given topic, adding that their brother or sister would probably tell me about it if they wanted to do so. In several cases, women who perceived their relationship with a brother or sister as unsatisfactory, expressed curiosity about what their siblings would have to say about them or about their relationship. I presume this curiosity might derive from them being unable to talk to their siblings frankly and 
openly, or being unconvinced that any interest on their part would be met with received favourably. They might also regret that their siblings did not experience and analyse their relationship so intensely, and wish that they would have. In most of such cases I did not receive any contact information of the brother or sister of my interviewee.

The fact that I had already spoken to one of the siblings affected not only my interviewees, but also my position as a researcher in their eyes, and had an impact on how I perceived it myself. What I learned in the interview with the first family member also had an influence on how I conducted the conversations that followed. One example of this is an interview with a young man who was much less willing to share details of his experiences and family history with me than his sister whom I spoke to earlier. Later on, during the analysis of both interviews, I realised that in this case it was easier for me to give up exploring certain issues because I had a sense of already having the appropriate knowledge gained during the interview with his sister. I unconsciously rejected my own initial assumption, that I would try to conduct each interview in such a way in order to obtain as full a picture of the relationship between the siblings as possible, one that was rooted in the history of a given family, and that I would not rely exclusively on those interviewees who find talking about their lives and the history of their family easier. During subsequent interviews, I avoided situations where I would have to rely on the knowledge gained in a previous conversation with a brother or sister of my interviewee.

In several cases my interviews were also affected by the common perception of family relationships as a topic belonging to the domain of psychology. This is confirmed both by the predominance of the psychological approach in the literature on various dimensions of siblings' lives, as well as by the opinions of some participants who assumed that I was a psychologist conducting a psychological study. Such a statement even came from a participant who received training in social sciences in the past. Talking about family and relationships with family members fits neatly into an increasingly more popular therapeutic discourse. Some of my subjects who had previously undergone therapy prior to the research referred to it in our conversations. The participants experienced a whole range of emotions: Some of them summed our meetings up with a conclusion that telling stories about their relationships with siblings was a pleasant experience, for others it was difficult to share their memories of sad events with me, and in some cases participants admitted that our conversations gave them an opportunity to get all the heavy emotions "out of their system", release their tensions and cast their burden on me. Such comments came from those participants who were very 
self-aware, reflective about their own experiences and de facto did not consider our conversations as an opportunity to solve their relationship problems with siblings. Some participants (this group was largely dominated by women) could find our conversations quasi-therapeutic, thought-provoking, encouraging them to reflect on their own experiences, or freeing them from the burden of not being able to share their feelings or opinions related to their siblings. I use the term "quasi-therapeutic" intentionally because I am not a qualified therapist and the formula of my study and the relationship between me and participants of my study is significantly different from the one characteristic in a true therapeutic relationship. I presume that some of my interviewees could find certain relief in contact with me, seeing it as an opportunity to share their difficult experiences with someone who expressed interest in them, not only on an individual level, but also as a valuable source to enrich our knowledge about society.

The challenge in this type of research is the need to make comparisons, which is one of the basic procedures used in qualitative research. As Melanie Mauthner [1998] and Miri Song [1998: 107] point out, participants in studies involving family members may also feel reluctant about comparing themselves with their siblings. According to some of my participants, making comparisons between children, as parents and other adults often do, was one of the behaviours which hurt them most and negatively affected their relationships with siblings. This was one of the reasons why I approached questions regarding sibling comparisons with a great caution. As one of the goals of my study was to understand the tensions between brothers and sisters, the sources of which, according to the research to date [see, for example, Bourdieu 2005; Conley 2004; Ferenc 2012], could also derive from the experience of inequality based on gender and class differences, I could not resign from the strategy of case comparison, both while collecting the data and later during the analysis.

The potential positive effect of my research on the participants can be evidenced by some of them sharing with me later how the interview provoked them to rethink certain issues and turned out to be an opportunity to look at their experiences from a different angle. For some interviewees, one advantage of participating in my research was the possibility to have contact with me as a professional who concentrates on various issues concerning siblings. As such, I was considered to be someone with indisputable, objective knowledge. The role of an expert on family relations attributed to me by some of the participants (usually women) was a challenge because my own perception of myself was that of someone still looking for answers to the questions I was asking, not of someone with reliable knowledge able to solve the problems appearing in family life of 
my interviewees. At the same time, I was willing to share with my respondents everything I had learned whilst researching the literature and conducting qualitative interviews. This approach was guided by the principles of reciprocity and truthfulness in my relationship with participants, both for ethical reasons and because of a genuine conviction that such a strategy allows the researcher to better understand the studied area [Harrison et al. 2001: 323-324]. In order not to influence the stories my respondents were recounting, I would usually do this at the end of the interview. Sometimes talking about the experiences of other people prompted my participants to reflect on new issues. This moment was usually part of the normalisation process and led to the end of the interview.

\section{(IN)EQUALITIES AND POWER DYNAMICS IN RESEARCH ON RELATIONSHIPS BETWEEN FAMILY MEMBERS}

The formula of my research, focused on the reconstruction of the dynamics of sibling relationships (and as such, also the relationships in their family of origin and in the sphere of social relationships in a broader sense), meant that my interviewees often generously shared information with me which, in all likelihood, they usually do not reveal to non-relatives. In the course of doing my research I experienced both surprising frankness on the part of my interviewees (as Dickson-Swift, Kippen, Liamputtong [2007: 331] point out, this experience is shared by many social scientists), as well as resistance or reluctance to answer some of my questions.

Taking part in a study which aims to explore various topics related to our relationships with relatives creates the opportunity to establish a unique connection between the researcher and the participant. My interviewees had various motives for participating in the study; many of them decided to be interviewed because, for one reason or another, they found the topic of their relationships with siblings to be important. For some it was a source of support and positive feelings, whereas for others any contact with siblings seemed to be a stressful experience, causing only resentment or suffering. One of my interviewees admitted at the very beginning of our interview that she had entered my study to demythologise family relationships, which in her view are romanticised in Polish society. In this and similar cases, I had access to intimate stories that were often associated with violence, hurt, inequality, feelings of exploitation, the inability to reach out to loved ones, and other difficult issues.

Conversations about family relationships are often emotionally charged. On one hand, sometimes participants summed the interview up in a way which 
expressed gratitude for the opportunity to recount their relationship with their siblings, or recall good, happy moments. On the other hand, however, their willingness to be honest with me often resulted in a need to share stories about situations and feelings which do not correspond with the commonly accepted perception of a family as a community of people tied together by a sense of caring and solidarity. Although, as I pointed out earlier, those participants who decided to put me in contact with their brothers and/or sisters were at least on relatively good terms with their siblings, they also shared some difficult experiences with me related to their sibling relationships.

My interviewees did not receive any financial or material compensation for their participation in the study; however, this does not mean that the interviews themselves were not a form of exchange. From the outset, my study was based on the idea of a reciprocal research relationship, supported by other researchers who make frequent references to feminist ideas in their work [Ribbens, Edwards 1998]. I began my study fully aware that inviting other people to tell me about their family relationships could lead to an expectation on their part that I would also share with them some of my family experiences. In several cases my interviewees asked me direct questions about my relationship with my sister or, more broadly, about my family history. I usually mentioned at the beginning of a conversation that I have an older sister in order to create an atmosphere of closeness and the safety of a mutual exchange. I left more elaborated comments for (potentially) the end, when the form of the interview was evolving more and more towards a free conversation, ending the actual interview.

Aware that as a researcher I have a greater power in the researcher-participant relationship (I am the one who asks questions, processes the data and presents them to academic and non-academic audience). Similarly to Patricia Ballamingie and Sherrill Johnson [2011] and Patricia Cotterill [1992], I recognise that power in this relationship may fluctuate and is not permanently assigned to one party. On several occasions my interviewees tried to take over by making inquiries and comments on my private life (for example, about some of my personal decisions) or by trying to avoid the questions I asked and move directly to reflect on the issues which were the focus of my study. I find it rather peculiar that such a strategy was more frequently adopted by those with a higher cultural capital (and therefore with a higher position in the social hierarchy of prestige) and those older than me. I interpret it as an attempt to restore the power relationship disrupted by the interview process. It could be the case that the interviewees who fit in this category very rarely find themselves in situations in their everyday lives when they are the ones who are expected to answer questions (very often concerning 
their private lives) asked by someone else. Women were more likely to engage in a more casual conversation with me at the end of the interview; conversations with men usually ended faster; we would part shortly after the voice recorder was turned off. However, there is limited scope in this study for any comparisons of the impact of the socio-cultural gender on the course of the interactions with research participants due to a significant majority of female participants.

Another strategy employed to prepare my interviewees for our meeting (in those instances where I had already talked to their brother or sister) was to discuss the course of their sibling's interview with them. One of the upper-class participants began our conversation by referring to the questions I had asked his sister (among others, on how the living conditions of the upper class changed after World War II, including the experience of losing property). Questions about a change in material status were intended to help me reconstruct the transformation of my interviewees' habitus. However, my interviewee rejected this question as rather naive or not irrelevant to the substance of understanding the family and attributing meaning to it in the post-aristocratic environment he belongs to. In this instance, a close link between the theory and practice of social research becomes evident: the relationship between me and my interviewees revealed the tensions described by Pierre Bourdieu and other scholars who explored class divisions [see., for example, Reay 2005].

\section{CONCLUSION}

Qualitative research on horizontal relationships, such as sibling relationships, which differ from case to case in terms of the number of diverse individuals, calls for creative, flexible research methods and techniques. The relatively small recognition of lateral relationships in the social sciences poses an additional challenge of how to present its relevance to both the academic audience and potential participants. By deciding to include in my research, accounts of one of the siblings as well as two or more family members, I strove to capture a nuanced picture of sibling relationships over their lifetime. The specific relationship dynamics and developing biographies of brothers and sisters were explained through the context of class reproduction and selection mechanisms and gender division, which generates diverse hierarchies of socially available patterns of femininity and masculinity.

The literature emphasises the importance of considering the perspective of all persons involved in a relationship; only then can we achieve a proper understanding of close relationships (family, intimate partners etc.) [see, for example, 
Sikorska 2019]. As I have shown in this article, the assumption that we should get to know the perspectives of all actors related by a given type of family bond may actually have just the opposite effect, namely, it may limit rather than expand access to the experiences subject to analysis. Conducting separate interviews with family members requires the researcher to be acutely aware of information confidentiality. Whilst conducting the research, I did not communicate to my interviewees any information obtained from their siblings. I also tried not to reveal what my previous interviewees had said and what they declined to comment on. In the case of interviews with other members of the same family, both myself and my interviewees had some prior knowledge before the meeting began, which at this stage neither researchers nor participants usually have. Having previously interviewed their siblings, I was already aware of certain facts from their own and their family lives. They were, however, also prepared for our meeting to some extent because they had already talked to their siblings. This shows that the power in the researcher/participant relationship is processual in nature. Although it is the researcher who asks questions and has control over the research material, participants often try to negotiate the course of the meeting or their position in it, marking in this way their agency and the degree of their influence on the research. At the same time, however, it is the researcher who is ultimately responsible for the well-being of everyone who participates in their study.

\section{BIBLIOGRAPHY}

Ballamingie Patricia, Sherrill Johnson. 2011. "The vulnerable researcher: Some unanticipated challenges of doctoral fieldwork". The Qualitative Report (16)3: 711-729.

Bank Stephen P., Michael D. Kahn. 1982. The sibling bond. New York: BasicBooks.

Bernard Jessie. 1972. The future of marriage. New York: World Publishing.

Bertaux Daniel. 1996. Le récit de vie: Perspective ethnosociologique. Paris: Nathan Université.

Bourdieu, Pierre. 2005. Dystynkcja. Społeczna krytyka władzy sadzenia, trans. P. Biłos. Warszawa: Wydawnictwo Naukowe Scholar.

Coles Prophecy. 2003. The importance of sibling relationships in psychoanalysis. London, New York: Routledge.

Coles Prophecy. 2015. "Sibling rivalry at work: From family to groups". Psychodynamic Practice (21)3: 254-264.

Conley Dalton. 2004. The pecking order: Which siblings succeed and why. New York: Pantheon Books.

Connidis Ingrid A. 2007. "Negotiating inequality among adult siblings: Two case studies". Journal of Marriage and Family 69: 482-499.

Cotterill Pamela. 1992. "Interviewing women: Issues of friendship, vulnerability, and power". Women's Studies International Forum (15)5-6: 593-606. 
Dickson-Swift Virginia, Erica L. James, Sandra Kippen, Pranee Liamputtong. 2007. "Doing sensitive research: What challenges do qualitative researchers face?". Qualitative Research (7) 3: 327-353.

Edwards Rosalind, Lucy Hadfield, Helen Lucey, Melanie Mauthner. 2006. Sibling identity and relationships: Sisters and brothers. Oxon: Routledge.

Ferenc Maria. 2012. Jak by to powiedzieć, to już nie moje życie jest. Relacje rodzinne osób awansujących". In: Style życia i porzadek klasowy w Polsce, M. Gdula, P. Sadura (eds.), 233-251. Warszawa: Wydawnictwo Scholar.

Freud Zygmunt. 1993. Totem i tabu. Warszawa: Wydawnictwo KR.

Graham Allan. 1980. "A note on interviewing spouses together". Journal of Marriage and the Family (42)1: 205-210.

Gold Deborah T. 1989. "Sibling relationships in old age: A typology". The International Journal of Aging and Human Development (28)1: 37-51.

Hammersley Martyn, Paul Atkinson. 2000. Metody badań terenowych. Poznań: Zysk i S-ka.

Harrison Jane, Losley MacGibbon, Missy Morton. 2001. „Regimes of trustworthiness in qualitative research: The rigors of reciprocity". Qualitative Inquiry (7)3: 323-345.

Hertz Rosanna. 1995. "Separate but simultaneous interviewing of husbands and wives: Making sense of their stories". Qualitative Inquiry (1)4: 429-451.

Irish Donald P. 1964. "Sibling interaction: A neglected aspect in family life research". Social Forces 42: 279-288.

Kasten Hartmut. 1997. Rodzeństwo. Ideały, rywale, powiernicy. Springer PWN: Warszawa.

Kaźmierska Kaja. 1997. Wywiad narracyjny - technika i pojęcia badawcze. In: Biografia a tożsamość narodowa, M. Czyżewski, A. Piotrowski, A. Rokuszewska-Pawełek (eds.), 35-44 Łódź: Uniwersytet Łódzki, Katedra Socjologii Kultury.

Korolczuk Elżbieta. 2019. Matki i córki we współczesnej Polsce. Kraków: Universitas.

Litwińska Katarzyna. 2010. Jedynaczki i jedynacy w świetle badań psychologicznych. In: Rozwojowe $i$ wychowawcze aspekty życia rodzinnego, T. Rostowska, A. Jarmołowska (eds.), 168-181. Warszawa: Wydawnictwo Difin.

Mauthner Melanie. 2000. "Snippets and silences: Ethics and reflexivity in narratives of sistering". International Journal of Social Research methodology (3)4: 287-306.

Mauthner Melanie. 2002. Sistering: Power and change in female relationships. New York: Palgrave MacMillan.

Malinowski Bronisław. 1984. Życie seksualne dzikich w pótnocno-zachodniej Melanezji. Dzieła. Vol. II. Warszawa: PWN.

Milevsky Avidan. 2016. Sibling issues in therapy: Research and practice with children, adolescents and adults. Nowy Jork: Palgrave MacMillan.

Mitchell Juliet. 2003. Siblings: Sex and violence. Cambridge: Polity Press.

Mitchell Juliet. 2014. "Siblings and the psychosocial". Organisational and Social Dynamics (14)1: $1-12$.

Mizielińska Joanna. 2017. Odmienne czy zwyczajne. Rodziny z wyboru w Polsce. Warszawa: PWN.

Morgan Robin. 1970. Sisterhood is powerful: An anthology of writings from the women's liberation movement. New York: Random House.

Olcoń-Kubicka Marta. 2017. Zastosowanie technik jakościowych w badaniu praktyk budżetowania w gospodarstwach domowych. In: Wykorzystanie metod jakościowych w badaniach zachowań i zjawisk ekonomicznych, W. Dymarczyk, Ł. Pyfel (eds.), 33-54. Łódź: Wydawnictwo Uniwersytetu Łódzkiego. 
Palska Hanna. 2002. Bieda i dostatek. O nowych stylach życia w Polsce końca lat dziewięćdziesiatych. Warszawa: Wydawnictwo IFiS PAN.

Pawlak Piotr. 2013. Dzieci z ADHD i ich rodzeństwo. Kraków: Oficyna Wydawnicza Impuls.

Pisula Ewa. 2007. Rodzice i rodzeństwo dzieci z zaburzeniami rozwoju. Warszawa: Wydawnictwa Uniwersytetu Warszawskiego.

Przybył Iwona. 2017. „Rodzeństwo w dobie denormalizacji zobowiązań rodzinnych: Wsparcie, zaufanie i konflikt". Studia Socjologiczne (225)2: 189-212.

Reay Diane. 2005. "Beyond consciousness? The psychic landscape of social class". Sociology 39(5): 911-928.

Ribbens Jane, Rosalind Edwards. 1998. Living on the edges: Public knowledge, private lives, personal experience. In: Feminist dilemmas in qualitative research: Public knowledge and private lives, J. Ribbens, R. Edwards (eds.), 2-23. London, Thousand Oaks, New Delhi: SAGE Publications.

Risman Barbara, Davis Georgiann. 2013. "From sex roles to gender structure". Current Sociology (61)5-6: 733-755.

Rokuszewska-Pawełek Alicja. 2006. „Wywiad narracyjny jako źródło informacji”. Media, Kultura, Spoleczeństwo 1: 17-28.

Rostowska Teresa. 2010. Psychospołeczne aspekty relacji interpersonalnych w podsystemie rodzeństwa bliźniąt monozygotycznych. In: Rozwój bliźniąt w ciagu życia. Aspekty biopsychologiczne, T. Rostowska, B. Pastwa-Wojciechowska (eds.), 101-123. Kraków: Oficyna Wydawnicza Impuls.

Rustin Margaret. 2018. Taking account of siblings - a view from child psychotherapy. In: Siblings in Development: A Psychoanalytic View, V. Lewin, B. Sharp (eds.). London, New York: Routledge.

Sikorska Malgorzata. 2019. Praktyki rodzinne i rodzicielskie we wspótczesnej Polsce - rekonstrukcja codzienności. Warszawa: Scholar.

Skeggs Beverley. 1997. Formations of class \& gender. Becoming respectable. Lancaster: Lancaster University.

Smoczyński Rafal, Tomasz Zarycki. 2017. Totem inteligencki. Arystokracja, szlachta i ziemiaństwo w polskiej przestrzeni spolecznej. Warszawa: Wydawnictwo Naukowe Scholar.

Song Miri. 1998. Hearing competing voices: Sibling research. In: Feminist dilemmas in qualitative research: Public knowledge and private lives, J. Ribbens, R. Edwards (eds.), 103-118 London, Thousand Oaks, New Delhi: SAGE Publications.

Schier Katarzyna. 2019. Dorosłe dzieci. Psychologiczna problematyka odwrócenia ról w rodzinie. Warszawa: Scholar.

Sherwin-White Susan. 2007. "Freud on brothers and sisters: A neglected topic". Journal of Child Psychotherapy (33)1: 4-20.

Stanisz Agata. 2013. Rodzina made in Poland. Antropologia pokrewieństwa i życia rodzinnego. Poznań: Agata Stanisz.

Szlendak Tomasz. 2015. Socjologia rodziny. Ewolucja, historia, zróżnicowanie. Warszawa: PWN.

Taylor Bridget, Hilde de Vocht. 2011. "Interviewing separately or as couples? Considerations of authenticity of method". Qualitative Health Research (21)11: 1576-1587.

Tyszkowa Maria. 1985. Badania nad uspołecznieniem i osobowością dzieci jedynych i mających rodzeństwo. In: Rozwój dziecka w rodzinie i poza rodzina, M. Tyszkowa (eds.), 9-63. Poznań: Wydawnictwo Naukowe UAM. 
Urbańska Sylwia. 2014. "Is apostasy from a family possible? The apostasy from an alcoholic-abusive family as a variant of (un)becoming a daughter - the case of Natalia". Qualitative Sociology Review (10)1: 80-103.

Willson Andrea E., Kim M. Shuey, Glen H. Elder Jr., Kandauda (K.A.S.) Wickrama. 2006. "Ambivalence in mother-adult child relations: A dyadic perspective". Social Psychology Quarterly" (69)3: 235-252.

Katarzyna Dębska

\title{
TO TAKIE PLOTKI. PROBLEMY I WYZWANIA ETYCZNE W SOCJOLOGICZNYCH BADANIACH JAKOŚCIOWYCH NAD RELACJAMI MIĘDZY DOROSLYM RODZEŃSTWEM
}

\begin{abstract}
Streszczenie
W badaniach nad relacjami rodzinnymi (np. matka-córka czy między partnerami) stosuje się różnorakie techniki (wywiady indywidualne z poszczególnymi członkami i członkiniami rodziny, diady, fokusy, obserwację etnograficzną), które mają na celu poznanie zróżnicowanych perspektyw i doświadczeń osób je tworzących. Takie podejście pozwala w bardziej wielowątkowy sposób analizować dane zagadnienie w porównaniu z sytuacją, gdy informatorem jest tylko jedna osoba z rodziny. Jednocześnie jednak angażowanie większej liczby rozmówców i rozmówczyń, których łączą nierzadko skomplikowane relacje emocjonalne, wiąże się z różnymi wyzwaniami o charakterze etycznym i metodologicznym. Rozważając tę problematykę, odwołuję się do moich doświadczeń z prowadzenia badania dotyczącego form i dynamiki relacji między dorosłymi braćmi i siostrami w ciągu życia. W badaniu uczestniczyło 55 osób (41 kobiet i 14 mężczyzn). W siedmiu przypadkach wywiady przeprowadziłam $\mathrm{z}$ więcej niż jedną osobą z rodzeństwa. W pozostałych przypadkach moi rozmówcy odmówili mi możliwości nawiązania kontaktu z ich braćmi i/albo siostrami. W artykule podejmuję kwestie związane z rekrutacją uczestników badania należących do tej samej rodziny, zarządzania poufnością informacji w sytuacji, gdy wywiady prowadzone są z osobami znającymi się ze sobą oraz relacjami władzy w trakcie badania.
\end{abstract}

Słowa kluczowe: poufność danych, rodzeństwo, wywiady jakościowe, relacje między badaczką a uczestnikami badań 